Crowdfunding as a tool to support sustainability-oriented initiatives: Preliminary insights into the role of product/service attributes

Stefania Testa - University of Genoa - Department of Mechanics, Energy, Management and Transport Engineering, Via all'Opera Pia, 11, Genova, Italy - stefania.testa@unige.it

Paolo Roma - University of Palermo - Department of Industrial and Digital Innovation, Viale delle Scienze, Palermo, Italy - paolo.roma@unipa.it

Maria Vasi - University of Palermo - Department of Industrial and Digital Innovation, Viale delle Scienze, Palermo, Italy - maria.vasi@unipa.it

Silvano Cincotti - University of Genoa - Department of Mechanics, Energy, Management and Transport Engineering, Via all'Opera Pia, 11, Genova, Italy - silvano.cicotti@unige.it 


\title{
Crowdfunding as a tool to support sustainability-oriented initiatives: Preliminary insights into the role of product/service attributes
}

\begin{abstract}
:
A common goal of current research seems to uncover whether crowdfunding (CF) could be considered an effective way to support sustainability-oriented initiatives in securing funding, due to diverging results emerging from literature. We claim that the objective of proving whether CF may benefit sustainabilityoriented initiatives could be misplaced; rather, we deem more fruitful to understand how critical are some attributes of products/services pursued within CF campaigns to benefiting sustainability-oriented initiatives and increasing their odds of success in CF. We focus on food-related projects as in this sector sustainability issues apply more than to any other human activities, and construct a unique sample of food CF campaigns launched and ended in the EEA (European Economic Area) countries on the world most popular rewardbased CF platform, i.e., Kickstarter. We identify campaigns with a sustainability orientation (SO) and perform an in-depth qualitative analysis, which allows us to classify them into meaningful clusters and subclusters. Our research suggests that the emphasis on egoistic/self-centered product attributes, rather than on altruistic/society-centered attributes, is generally more crucial to facilitate CF support to sustainabilityoriented projects. However, the emphasis on altruistic/society-centered attributes emerges to be more beneficial for initiatives specifically supporting local products. Our results also suggest that reward-based CF is not suitable for sustainability-oriented projects targeting disadvantaged individuals/groups. These results offer both theoretical and empirical contributions to the literature as well as practical implications.
\end{abstract}

Keywords: crowdfunding; sustainability; food; product attributes, qualitative research. 


\section{Introduction}

Among the multiple factors affecting current business, political and public spheres, one seems to stand out: sustainable development (SD) (Sachs, 2015), most famously expressed in the Brundtland Report's definition as meeting "the needs of the present without compromising the ability of future generations to meet their needs" (WCED, 1987, p. 43). The actors that interplay to affect SD range from governments to international institutions, from consolidated enterprises to start-ups and individuals (Elliot, 2012). The realization of initiatives aimed at promoting SD requires funding which is not always easy to obtain (Hörisch, 2015; Calic and Mosakowski, 2016). In this context, crowdfunding (i.e., a new funding method where investors, mainly consisting of ordinary citizens, support an idea providing small amounts of money and thus contribute to its realization, Bruton et al., 2015) is enthusiastically discussed in the media as an alternative means to finance sustainability-oriented initiatives (e.g., Park, 2012; Harte, 2013; Thorpe, 2014).

Nevertheless, the academic literature does not share the same enthusiasm and, due to diverging results emerging from research (Hemer, 2011; Bartenberger and Leitner, 2013; Lehner, 2013; Bonzanini et al., 2015; Hörisch, 2015; Calic and Mosakowski, 2016), the debate on whether crowdfunding (CF) could be considered an effective way to support sustainability-oriented initiatives is still open (see Testa et al., 2019). In this debate, we suggest that the objective of proving whether CF may benefit (or not) sustainabilityoriented initiatives could be misplaced. Rather, we think it is more fruitful to understand how critical are some attributes of product/services pursued within CF campaigns to benefiting sustainability-oriented projects and increasing the odds of success in CF. This research question is inspired by previous literature claiming that product/service attributes do have an impact on purchasing behavior of sustainability-oriented products (Crane, 2001; Auger et al., 2003; 2008; 2010; De Pelsmacker et al., 2005; Bougherara and Combris, 2009; Schäufele and Hamm, 2017). Such considerations have been developed in the broader context of consumer purchasing behavior but we argue they could also be applied in the context of CF (specifically, reward-based $\left.{ }^{1}\right)$. Indeed, Chan and Parhankangas (2017, page 238) claim that in reward-based CF “(...) crowdfunders mainly contribute in exchange for future products or services, meaning that they behave like general consumers" (emphasis added). Therefore, reward-based CF can be viewed as a channel for early access to products and a form of pre-sale. Indeed, the reward in this type of CF very often consists of the product/service that the campaign proponent aims to commercialize and campaign contributors are very often consumers who show real interest in the product to the extent that they are willing to commit to buy

\footnotetext{
${ }^{1}$ Following Cholakova and Clarysse (2015), crowdfunding is broadly subdivided into four models: donation, reward, equity, and lending-based crowdfunding. Donation-based crowdfunding: the individual donates money to a specific project with no expectation of financial or material returns. Reward-based crowdfunding: the individual pledges an amount of money with the expectation that he/she will receive a tangible (but non-financial) reward, e.g., a product or service. Equity-based crowdfunding: the individual makes a small investment in a project in order to have a stock in the project. Lending-based crowdfunding: the individual lends a small amount of money to other individuals through a platform, with the expectation of being paid back with interests.
} 
early in advance even at the risk of losing their investment in the case of product development failure (Cholakova and Clarysse, 2015; Roma et al., 2017; Kuppuswamy and Bayus, 2018; Roma et al., 2018).

In order to collect insights on the product/service attributes benefiting sustainability-oriented initiatives, we focus on food industry. This is because the food industry is probably the area where environmental issues (e.g., issues related to the production of safer food without pesticide residues or natural food enhancing ecosystem qualities, or carbon-neutral food contributing to mitigating climate change, etc.) apply more than to any other human activities given that food provision is the human activity with the single largest environmental impact (Aiking and De Boer, 2004; Notarnicola et al., 2017). Furthermore, the food sector has a unique set of sustainability issues not only on environmental but also on social fronts such as the production of fair-trade food contributing to social justice (Pullman et al., 2009). Therefore, the food industry is arguably the most relevant industry setting to study topics connected to sustainability (such as the role of crowdfunding in supporting sustainability-oriented initiatives) and definitely represents a significant ground for providing insights on related issues. In addition, the food industry is one of the most important industries in terms of economic impact, generating a turnover worldwide more than $\$ 108$ billion worldwide (Statista, 2019) and an employment level among the highest ones. ${ }^{2}$

To our scopes, we conduct a qualitative research on food CF campaigns launched in the period 2011-2015 on Kickstarter, the world's most popular reward-based platform (over $\$ 3.5$ billion raised by over 14 million individuals, up to February 2018). These CF campaigns have been analyzed by means of in-depth qualitative content analysis.

Our research contributes to the literature about the role of reward-based CF in promoting SD, by introducing and fine-tuning concepts from the theory of purchasing behaviors of sustainable products as an overarching framework for explaining the CF performance of sustainability-oriented campaigns. By way of anticipation, our results suggest that some attributes of products/services pursued within sustainability-oriented campaigns do have an impact on the success of these campaigns. In particular, the emphasis on egoistic/self-centered product attributes, rather than on altruistic/society-centered attributes, is generally more crucial to facilitate CF support to sustainability-oriented projects. However, the emphasis on altruistic/society-centered attributes emerges to be more beneficial for initiatives specifically supporting local products. Finally, our results suggest that reward-based CF is not suitable for sustainability-oriented projects targeting disadvantaged individuals/groups as these initiatives tend to be associated more with donation-based platforms rather than reward-based CF. Accordingly, we build a theoretical framework by developing several propositions on the role of these attributes in the success of sustainability-oriented CF campaigns.

This article unfolds as follows. Section 2 outlines the current debate about the role of CF in promoting sustainability-oriented initiatives while Section 3 provides the key inspiring concepts of this study, namely

\footnotetext{
2 According to FAO statistics, only agriculture sector employs around 1 billion people globally (see http://www.fao.org/3/i2490e/i2490e01b.pdf).
} 
product/service attributes affecting purchasing decisions of sustainable products/services. Section 4 describes the methodology. Section 5 contains the findings, the propositions, the theoretical framework, and the relative discussion. Section 6 reports on conclusions, limitations and future developments.

\section{The role of $\mathrm{CF}$ in promoting sustainability-oriented initiatives: current debate}

When launching their sustainability-oriented initiatives, entrepreneurs often fail to successfully communicate with conventional financiers (Lehner, 2013), who consider expected yields, security of the investment and accounting liquidity as the most important investment criteria. Indeed, several authors (e.g.Ortas et al., 2013; Demirel and Danisman, 2019) claim that a central obstacle that hinders SD is the lack of funding. In this context, $\mathrm{CF}$ is enthusiastically discussed in the media as an alternative means to finance sustainabilityoriented initiatives (e.g., Park, 2012; Harte, 2013; Thorpe, 2014). However, academic contributions on this topic are still rare and contradictory, despite several calls to fill this gap (see e.g., Bocken, 2015, Testa et al., 2019). Furthermore, to our knowledge, there is lack of research on CF and sustainability in the food context, with only a few exceptions. ${ }^{3}$ Therefore, in the absence of a specific body of literature, we refer in general terms to the current literature on CF and sustainability. Authors claiming the potential of CF in the context of sustainability essentially rely on the literature affirming that crowd investors' motivations are different from those of traditional financial investors (e.g., Lindenberg and Steg, 2007; Aitamurto, 2011; Lehner, 2013). As Lehner $(2013,2)$ states: "Crowd investors typically do not look much at collaterals or business plans, but at the ideas and core values of the firm." In other words, crowd investors participate because of non-material rewards such as the desire to support specific causes that may be close to their own hearts or the desire to help others (Gerber and Hui, 2013; Belleflamme et al., 2014; Lehner and Nicholls, 2014; Allison et al., 2015). In this context, social and psychological factors may be equally or more important than strictly financial returns. This suggests that narrative may play a significant role in successful crowdfunding activities by establishing a convincing and compelling investment story (Allison et al., 2017; Manning and Bejarano, 2017). According to Lindenberg and Steg (2007), crowd investors may be moved by altruistic or normative reasons, i.e., reasons meeting their (or their community's) moral or ethical norms and select social ideas they deem worthy and needed (Lehner, 2013). Dóci and Vasileiadou (2015) affirm that actually a combination of motivations may drive participation in CF campaigns ranging from hedonic goals (individuals want to improve the way they feel in a specific moment), gain goals (individuals aim at increasing or protecting their resources) and normative goals (see above). Heterogeneity of motivations is important because initiatives relying only on ideological aims (i.e., normative goals) have a limited capacity to grow, as they have difficulties linking to a wider range of actors and scaling up (Seyfang et al., 2014). According to Calic and Mosakowski (2016), individuals engaged in CF generally share a 'loose ideology'. Different CF platforms may have different loose ideologies, depending on the mission of the platform and

\footnotetext{
${ }^{3}$ These exceptions are: Arcese et al. (2015), who focus on a specific sustainability-oriented CF campaign - Back to the Root - as an exemplificative successful case, and Misso et al. (2019) who report preliminary findings of an ongoing research project on $\mathrm{CF}$ and sustainability in the food context.
} 
the values and beliefs of individuals frequenting the platform. For example, Calic and Mosakowski (2016) argue that, given the demography of crowdfunders on Kickstarter, the loose ideology of that platform is supportive of a sustainability orientation. According to these authors, reward-based CF offers little opportunity for due diligence because information available is limited, many ventures have little history, many entrepreneurs have little experience, and data is typically self-reported. Furthermore, reward-based CF involves not only family and friends but also backers ${ }^{4}$ who are geographically and socially distant from the entrepreneurs they support. Therefore, backers cannot rely much on entrepreneurs' social capital to reduce information asymmetries. In turn, this provides room to other considerations rooted on the loose ideology characterizing the platform, rather than to traditional mechanisms to reduce uncertainty and incentivize funding. Beyond claiming the potential of CF in the context of sustainability (Bartenberger and Leitner, 2013; Goodman and Polycarpou, 2013; Royal et al., 2014; Vasileiadou et al., 2015; Bonzanini et al., 2015; Chiang, 2015; Lam and Law, 2016; Belz and Binder, 2017), some conceptual and empirical works suggest a positive relationship between sustainability orientation and the likelihood of success of CF projects (e.g., Bartenberger and Leitner, 2013; Hemer, 2011; Lehner, 2013; Calic and Mosakowski, 2016). For example, Calic and Mosakowski (2016) find that both environmental and social sustainability orientations of a project positively affect its success in $\mathrm{CF}$, and that these relationships are partially mediated by project creativity and third-party endorsements.

Very different results are reported by Hörisch (2015), who does not observe in his research any positive connection between sustainability orientation (specifically environmental orientation) and CF success. Actually, his findings indicate that environmental sustainability orientation could negatively affect the success of crowdfunding campaigns, revealing that environmentally oriented projects are less likely to reach their funding targets than any other category of projects analyzed, and achieve the lowest average share of the targeted amount. Similarly, Lagazio and Querci (2018) find that CF to support social impact initiatives (e.g., referring to the well-being of animals, communities and the environment) does not perform well.

These results are in line with part of the CF literature claiming that crowdfunders are likely to act similarly to conventional financiers (see for instance, Moss et al., 2015) as they "evaluate the quality of the product, the team and the likelihood of success". Therefore, according to this view, other elements than sustainability orientation are determinant for the projects' funding success, such as the prospect of financial return (Ordanini et al., 2011) or early access to products or access to products at better prices (Belleflamme et al., 2010; Roma et al., 2018).

Finally, mixed results are reported by Vismara (2019), who finds that - in equity CF - sustainability orientation does not increase the chances of success or the chances of engaging professional investors, but attracts a higher number of non-professional investors. Overall, this evidence further confirms the

\footnotetext{
${ }^{4}$ The term backer refers to someone who contributes to a reward-based crowdfunding campaign (like those on Kickstarter).
} 
emergence of conflicting views in the extant research on whether and how CF can support sustainabilityoriented initiatives. In turn, this hints at the possibility that the CF success of sustainability-oriented initiatives may be contingent upon a number of attributes of the product/service that the given initiative intends to commercialize, which is the focus of our study. Therefore, as reward-based CF can be assimilated, to some extent, to a pre-sale mechanism, in the next section we discuss the most relevant product/service attributes that are likely to affect consumer purchasing decisions of sustainable products/services.

\section{Product/service attributes affecting purchasing decisions of sustainable products/services}

Prior literature shows that consumers have preferences for some characteristics (or attributes) of products rather than for the products themselves (Lancaster, 1966; Rosen, 1974). Each product can be understood as a bundle of attributes, which can be either tangible or intangible (Rosen, 1974; Crane, 2001; Auger et al., 2010). A tangible attribute is one that is concrete, physical, and objective, whereas an intangible attribute (e.g. brand or country of origin) is abstract, beneficial, and subjective (Auger et al, 2010). Intangible features are inherently difficult to describe and characterize compared to tangible attributes (ibidem). However, as products become more physically similar and thus difficult to compare, it is well known that intangible attributes play an increasingly strong role in consumer purchasing decisions (Lefkoff-Hagius and Mason, 1990). Among intangible attributes, there is a specific group referred by some authors as 'social' (Auger et al., 2003; 2008; 2010; Ubilava et al., 2010) or 'ethical' (Crane, 2001; Tallontire et al., 2001; Maehle et al., 2015) attributes. They include, for example, environmental as well as labor conditions (e.g., child labor) under which a product/service is produced (e.g., Auger et al., 2010). Other authors explicitly focus on green product attributes (Magnusson et al., 2001; Prakash, 2002). Irrespective of the categorization, these attributes are product characteristics that are not immediately functional and represent aspects of the product that could be added or removed without changing the functionality of the product significantly. These attributes fully or partially fall under the realm of public goods (i.e., non-excludable, non-rivalrous goods) (Moser et al., 2011). They encompass outcomes related to public health, environmental conservation, creation of employment, support to small-scale agriculture and local rural communities, production under marginal and/or disadvantaged conditions, workers' rights and so forth. We will refer to them as sustainability attributes.

The literature on the importance of sustainability attributes is relatively new and results are controversial. Some authors suggest that these attributes play an increasingly important role in driving consumer purchasing decisions (Auger et al., 2010; Howard and Allen, 2006; Van den Heuvel et al., 2007). Other authors, on the contrary, claim that consumers mainly consider egoistic attributes (i.e., those that provide consumers with direct and visible positive benefits, thereby serving self-interest needs), such as quality, taste, price, and brand, rather than sustainability ones (Magnusson et al., 2001) and, at the end, tend not to purchase sustainability-oriented products. A third group of authors sit in the middle and claim that 
consumers do consider sustainability attributes in their purchasing decisions but that these attributes are often pushed to the background. That is, consumers firstly focus on egoistic product attributes, and secondly on sustainability attributes (Schuitema and de Groot, 2015. Annunziata and Scarpato, 2014). More in general, consumers tend to be more conscious about the un-ethical production practices rather than eager to support socially friendly production (Folkes and Kamins, 1999). This is because, broadly speaking, many people believe that individuals have a responsibility not to do harm (e.g., not to exploit child labor), but do not believe that others have a right to be helped (e.g., to provide employment for victims of disasters) (ibidem).

It is worthwhile to note that consumers are concerned about very specific issues and are unlikely to react to sustainability attributes that are "too broad" (Devinney et al., 2006). Furthermore, consumers' evaluation of sustainability attributes tends to be context specific (e.g., the exploitation of child labor in the manufacturing of athletic shoes versus the use of animal testing in the production of bath soap) (ibidem).

Concerning food products, the bundle of attributes constituting a good is continuously evolving (Arunachalam et al., 2009). Lusk and Briggeman (2009) introduced eleven broad attributes (they speak about "food values") positively associated with food purchasing decisions: naturalness, taste, price; visual appeal; healthiness; safety; origin; convenience; environmental impact; social fairness and tradition. Some of these values can be considered attribute per se (e.g., taste). However, they may also potentially represent numerous product attributes. These broad attributes can be classified as either personal (i.e., self-centered/egoistic attributes) or social (i.e., society-centered/sustainability attributes). For example, the values of social fairness and environmental impact would fall into the latter category, while healthiness and taste in the former category. Concerning more specific attributes, organic is a sustainability attribute, which has considerably increased in consumers' awareness, purchase penetration and research interest over the last decade (see e.g., Aertsens et al., 2009; Perrini et al., 2010; Willer and Kilcher, 2012). It has a singular position among all food attributes as it uniquely combines a number of important issues, such as food safety (Harper and Makatouni, 2002), better taste (Chryssohoidis and Krystallis, 2005), healthiness (Magnusson et al., 2003), environmental benefits (Magnusson et al., 2003), and ethical concerns and fairness (Briggeman and Lusk, 2011). Localness is another attribute largely taken into account in food purchasing decisions as well as animal welfare and fair wages and trade (Deemer and Lobao, 2011; Howard and Allen, 2010).

In summary, what emerges from this stream of literature is that sustainability attributes in general tend to influence purchasing decisions. Yet, the extant literature suggests that only a few consumers are willing to sacrifice basic functional attributes in favor of the sustainability ones (Auger et al., 2008; Dekhili and Achabou, 2013). In fact, sustainability attributes, such as environmental friendliness and healthiness, are not mutually excludable in relation to price and taste (Maehle et al., 2015). In developing our framework as the output of a qualitative analysis, we will use and apply the lens of consumer purchasing decisions of sustainable products developed in the literature above to the context of CF.

\section{Methodology}


As shown in Section 2, the role of CF in the context of sustainability-oriented initiatives remains debated with diverging results emerging from empirical studies. In order to contribute to this debate, we suggest that the objective of proving whether CF may benefit or not sustainability-oriented initiatives could be misplaced. Rather, we think it could be more fruitful to understand how critical are some attributes of product/services pursued within CF campaigns to benefiting sustainability-oriented initiatives. In order to understand this, we conducted a qualitative research (Yin, 2017) aimed at moving from specific observations to a more generalized understanding of the phenomenon, which ultimately conducts to a framework summarizing a number of propositions. In line with qualitative research aims, the main objective is not to "generalize" findings in the statistical sense but to promote "analytical generalization" (Yin, 2017) and help derive constructs for theory building (Eisenhardt, 1989). Specifically, we selected all food CF campaigns started and ended on the online platform Kickstarter from 2nd June 2011 to 2nd December 2015, related to initiatives localized in the following countries of the European Economic Area (EEA): Austria, Belgium, Bulgaria, Croatia, Cyprus, Czech Republic, Denmark, Estonia, Finland, France, Germany, Greece, Hungary, Iceland, Ireland, Italy, Latvia, Liechtenstein, Lithuania, Luxembourg, Malta, Netherlands, Norway, Poland, Portugal, Romania, Slovakia, Slovenia, Spain, Sweden, Switzerland and United Kingdom. We chose this American reward-based platform for several reasons. First, the choice of focusing on a reward-based platform lies on the fact that to date reward-based CF is one of the most prominent models of $\mathrm{CF}$ for product and service innovation in terms of both scale and breadth (Cholakova and Clarysse, 2015). Second, the worldwide crowdfunding platform activity report (Profatilov et al., 2015) claims that Kickstarter is the most popular reward-based platform internationally. Third, unlike other platforms, it is neither restricted to projects with a fixed funding target nor restricted to funders from the United States. Fourth, focusing on Kickstarter as a crowdfunding platform facilitated case access and limited extraneous variation (Eisenhardt, 1989). Moreover, we can expect crowdfunders in this type of platform being interested in sustainability issues given that the loose ideology associated to Kickstarter is generally supportive of a sustainability orientation (Calic and Mosakowski, 2016). We chose to limit the analysis to projects launched only in EEA countries in search of homogeneous conditions in terms of sustainability issues. First, despite different food cultures among European geographic areas (see e.g., Savino et al., 2018), as noted by Reisch et al. (2013), in most European countries it is possible to identify some common food-consumption trends relevant to SD (e.g., increase in meat consumption, higher focus on well-being and healthy lifestyles, spreading of overweight conditions and obesity, common dominant opinions about genetically modified organisms and nanotechnologies). Second, good practices that can be developed in the food landscape and have repercussions on sustainability are to some extent determined by decisions made by the EEA joint committee concerning food and agricultural issues (such as protecting the environment through criminal law, novel food and novel food ingredients, animal by-products, etc.) (EFTA, 2016). We considered the period 2011-2015 for two main reasons. First, we wanted to capture a period where Kickstarter started growing significantly 
and reached substantial size, e.g., more than 1 billion pledged amount overall. ${ }^{5}$ Second, we noted that after 2015 the number of campaigns in the specific category of food increased to the extent that they would not be suitable for a qualitative analysis, which by nature requires in-depth investigation of every campaign in the sample. ${ }^{6}$

During the considered period, we found 1,643 initiatives labeled as Food Initiatives by Kickstarter. However, we had to delete 186 projects whose campaign was cancelled or suspended before the end of the campaign. ${ }^{7}$ Similarly, 179 campaigns were still in progress and therefore not considered. Furthermore, we removed campaigns related to occasional non-profit projects focusing on the organization of festivals, fairs, exhibitions, because these campaigns were not explicitly aimed at commercializing food products directly by means of the CF platform. Finally, we excluded those projects that, despite having been published in the category food, were not pertinent. Therefore, the final dataset comprises 1,113 campaigns. As a first step, we distinguished campaigns having a sustainability orientation (SO projects) and those not having a sustainability orientation (NSO projects). In order to practically distinguish between SO and NSO projects, we carefully analyzed the value propositions (i.e., product/service offering) formulated in the project. We translated all project descriptions and related value propositions into English when written in a different language. Based on these premises, we designated 235 initiatives as having a sustainability orientation (21\% of the total, the full list of projects is available upon request).

To accomplish our research, we performed a content analysis (Krippendorf, 2004; Duriau et al., 2007). Content analysis is, at its simplest, a research technique used to determine the presence of certain words or concepts within text. Stempel (1981, p. 119) suggested a broad view of content analysis, what he called 'a formal system for doing something that we do informally rather frequently, drawing conclusions from observations of content'. Two researchers (in line with suggestions by Duriau et al., 2007) were involved in reading the value propositions of the projects and distinguished between SO and NSO projects. Because each

\footnotetext{
${ }^{5}$ The exponential growth of the crowdfunding phenomenon on Kickstarter occurred precisely in the considered period as can be seen for instance from Kickstarter statistics available at https://www.kickstarter.com/2billion.

${ }^{6}$ We obtain more than a thousand campaigns by restricting to their period 2011-2015. This is already a very high number for a qualitative research like ours. Extending to years past 2015 would have certainly generated a sample hardly manageable for the type of study we aimed to perform.

${ }^{7}$ Campaign cancellation/suspension may happen for different reasons: for instance, Kickstarter may suspend the campaign because it violates some platform rules, or the project proponent can cancel the campaign because of the occurrence of technical problems in development (some entrepreneurs have stopped their campaigns and launched them subsequently) or simply because it appears clear that he/she cannot reach the goal. Eliminating these projects is a common practice in prior crowdfunding literature (e.g., Mollick, 2014; Colombo et al., 2015; Roma et al., 2017) because otherwise it is difficult to retrieve all relevant information. While, as mentioned, the inability to reach the goal could be one of the reasons why a campaign is cancelled, it is not the only reason. Therefore, eliminating these campaigns does not necessarily mean that potentially less successful projects are eliminated. There are indeed some projects that were performing quite well before the end of the campaign, but they were suspended by Kickstarter despite the fact they were being very successful with an amount pledged higher than the goal (see for instance the case of the food project https://www.kickstarter.com/projects/43438555/honey-love-organic-pure-all-naturalhoney?ref=discovery_category_ending_soon\&term=suspended). Finally, the number of these projects is quite limited compared to the total number of projects analyzed in the sample. Therefore, in light of these considerations, their exclusion should not affect our findings significantly.
} 
researcher interprets the data according to his/her subjective perspective and co-researchers could come up with an alternative interpretation (Sandelowski, 1995), several techniques are suggested in order to reach agreement (Graneheim and Lundman, 2004). Content validation was made both by using a research assistant to support coding issues and by promoting dialogue among the researchers to agree on the way in which the data were labeled, as suggested by Graneheim and Lundman (2004); Burla et al. (2008) as well as Moritz et al. (2015). Any passages where a coder had doubts (which only occurred in less than $10 \%$ of instances) were discussed, until agreement was reached on the appropriate code (disagreement resolution in four cases required additional coding from a research assistant who read the campaign value proposition and assigned the coding). By using this approach there is no need of computing intercoder reliability coefficients (such as the Krippendorf's Alpha) because these measures are utilized when the coders operate fully separately and independently (Lombard et al., 2002), which was not our case.

Agreeing on what constitutes sustainability is a difficult task (Reisch et al., 2013), a challenge fueled by inconclusiveness and sometimes even contradiction in the scientific evidence. Sustainability is socially and politically constructed (Ilbery and Maye, 2005). Different stakeholders may have completely different views upon the topic (Farla et al., 2012) and objectives could be in conflict. Nevertheless, several relevant organizations (e.g., DEFRA, 2006; SDC, 2005, 2009) have tried to define practical criteria which must be fulfilled in order to define "sustainable food and drink", such as a product originating from the closest practicable source (to support local communities and cultures, to keep transportation impacts low, and to improve supply chain transparency); being safe, healthy, and nutritious for consumers in shops, restaurants, schools, hospitals, and so forth; providing a viable livelihood for farmers, processors, and retailers; not exploiting employees in terms of rights, pay and conditions; respecting biophysical and environmental limits in production and processing while reducing energy consumption and improving the wider environment; and respecting the highest standards of animal health and welfare compatible with the production of affordable food for all sectors of society.

The method of analysis chosen for this study was a hybrid approach (e.g., Fereday and Muir-Cochrane, 2006; Fischer et al., 2015) and it incorporated both the data-driven inductive approach of Boyatzis (1998) and the deductive a priori template of codes approach outlined by Crabtree and Miller (1999). The latter involves a template in the form of codes from a codebook to be applied as a means of organizing data for subsequent interpretation. When using a template, a researcher defines the template (or codebook) before commencing an in-depth analysis of the data. For this study the codebook was developed based on the categories defined by SDC (2009), i.e., Healthy Food; Environmental Sustainability; Social Sustainability; and Animal Welfare. These categories (top-level codes) represent the key aspects of sustainable food that are widely accepted in the literature and thus served as a construct for the deductive part of the data analysis.

It is worth noting that classifying a campaign into one category was not sometimes an easy task because the same initiative may potentially yield, for example, both environmental and health dividends (see, for 
example, all the initiatives based on organic supply and see Willer and Kilcher (2012) on this issue). In these cases, we labeled the initiative based on the dominant discourse (i.e., the most frequent words and concepts) used in the value proposition formulated by the proponent(s). Our interest is on how the project proponent describes the product/service offering, not on consequences or results to which the proponent does not attach importance. In cases where different types of objectives were embraced, projects were assigned to the category representing proponents' primary focus. Beyond the judgments of researchers involved, we also relied on a word cloud technique (freeware wordclouds.com). A word cloud is a special visualization of text in which the more frequently used words are highlighted by occupying more prominence in the representation. Such a technique is a useful tool to get a fast and visually rich way to enable researchers to have some understanding of data at hand (McNaught and Lam, 2010). Word clouds can be a useful tool for preliminary coding and for validation of previous coding. We used the tool ex post by applying the word cloud tool on the campaigns' descriptions in order to have a visual confirmation of the dominant objective.

During the coding process of value propositions according to the codebook, inductive codes (second-level codes) were also assigned to segments of data describing a new theme observed (Boyatzis, 1998). These additional codes can be either separate from the predetermined codes or expand a code from the manual. They have been created by each of the researchers and further grouped and combined based on their semantic familiarity when possible. In total twelve second-level codes, expanding codes from the manual, were identified, after the removal of doubles and the merging of some codes (see next section for the detailed description of these second-level codes).

These codes are referred to as "thematic clusters" (De Wet and Erasmus, 2005). This collaborative grouping of codes required deliberation to reach consensus among researchers, an approach referred to as "investigator triangulation" in the literature (Flick, 2004) and aimed at decreasing subjective bias and increasing reliability in the qualitative clustering process. As a result of the deductive and inductive coding phase, each project was assigned to one of the four top-level codes and to one of the twelve additional thematic clusters.

As an additional code separate from the predetermined codes, the self-centered/individualistic/egoistic orientation was identified (see next section).

Finally, out of the 235 SO campaigns, we distinguished between successful (84 campaigns) and unsuccessful SO campaigns (151 campaigns). Following Pitschner and Pitschner-Finn (2014), the success of CF campaigns is understood as their ability to acquire the capital needed to start the project. On Kickstarter, similarly to most of the other platforms, project creators define ex-ante a target amount they initially need for realizing their project. Kickstarter adopts an 'all or nothing” approach, which implies that funders' contributions are transferred to the project proponent only if the campaign goal is reached or exceeded. Thus, a CF campaign was classified as a successful campaign if the target amount was reached or exceeded. By distinguishing between successful and unsuccessful projects we aim at collecting insights on the potential impact of different attributes of products/services pursued within SO projects on backers' funding decisions. 


\section{Findings and discussion}

Table 1 provides an overview of the SO campaigns investigated in this study.

Please insert Table 1 about here

In the following, we show and discuss the findings of our qualitative research. As anticipated in the introduction and methodology sections, we argue that the potential of CF as a tool to support sustainabilityoriented initiatives in securing funding could be connected to specific attributes of products/services featured in the campaigns. Based on the analysis of the data, we make some observations revolving around these attributes. These observations are translated into propositions (following Whetten, 1989) and confronted with existing literature to determine and delineate the contribution of each of our propositions (Shepherd and Sutcliffe, 2011). We conclude the section by presenting the framework that summarizes the propositions developed.

The overall distribution of the sustainability attributes across the value propositions of the campaigns examined reveals an extensive share for the attribute "Environment Sustainability", followed by "Healthy Food", which together account for almost $80 \%$ of the entire dataset (see Table 2). The projects proposing products and services that feature attributes related to environmental sustainability are also those displaying the greatest success rate (see Table 2).

Please insert Table 2 about here

The twelve thematic clusters that resulted from the second-level codes developed inductively by the researchers involved in this study provide a more refined picture of the sustainability attributes emphasized in the campaigns' value propositions. Table 3 contains these twelve second-level codes, the number of successful projects, the general value proposition on which they stand and an example of value proposition.

Please insert Table 3 about here

Concerning the top-level code "Environment Sustainability", two thematic clusters are related to waste and account together for the biggest percentage ( $81 \%$ of total projects). It refers to issues related both to waste minimization and waste valorization, connected respectively to the thematic clusters "Maximize Material and Energy Efficiency" and "Create Value from Waste".

Concerning the top-level code "Healthy Food", organic food is the biggest thematic cluster $(43 \%$ of the Healthy Food projects) and the one with the highest success rate (42\% versus $39 \%$ of "Maximize Health Efficiency" and 29\% of "Increase Local and Seasonal Food Consumption" thematic clusters). This is not surprising since, as anticipated in Section 3, the organic feature is one of the sustainability attributes, which 
has considerably increased in consumer awareness and purchase penetration over the last decades (Aertsens et al., 2009; Perrini et al., 2010; Willer and Kilcher, 2012).

Concerning the top-level code "Social Sustainability", the thematic cluster "Fair Trade" stands out and it accounts for $40 \%$ of projects in this group. Although the attribute of fair-trade may incorporate environmental issues as well, in the campaigns under investigation this is communicated to the crowd through other elements, such as fair prices for small farmers and other community-level benefits (Raynolds et al., 2004). The community concept is at the core of both "Support Communities in Developing Countries Fair Trade" and "Support Local Communities" thematic clusters.

Concerning the top-level code "Animal Welfare", the two thematic clusters identified (i.e., "Improve Animal Welfare" and "Avoid Consumption of Animal Ingredients - Vegan Food") are equally distributed, each accounting for $50 \%$ of the projects in this group. However, the two thematic clusters exhibit rather different results in terms of success performances (see Table 3).

The number of projects falling into each specific thematic cluster is highly heterogeneous. This suggests that not all sustainability attributes are viewed as equally legitimate and feasible by CF campaigns proponents (see Table 3, reporting the absolute number of projects in each thematic cluster). The success rate is also heterogeneous among these thematic clusters (see Table 3), suggesting the interesting point that backers do not view all sustainability attributes as equally interesting. This is consistent with previous research described in Section 3 claiming that a specific set of sustainability attributes might impinge upon consumer concerns and their purchasing decisions (Devinney et al., 2006).

Specifically, from our observations, we noticed a great number of projects whose value propositions emphasize the localness attribute. Indeed, if we sum up projects included in the two thematic clusters "Supporting Local Communities" (10 projects in the "Social Sustainability" group) and "Local and Seasonal Food" (17 projects in the "Healthy Food" group), we obtain a large number of SO projects, which indicates a relevant interest by sustainability-oriented campaigns' proponents towards locally oriented initiatives. A relatively high total success rate (37\% versus $36 \%$ of SO projects in general) confirms a considerable interest by backers as well. However, our qualitative analysis suggests that a localness attribute emphasizing publicly oriented benefits (such as supporting local small farmers) rather than privately appropriated benefits (such as healthiness) may better act as a condition for the success of sustainability-oriented campaigns. Indeed, the success rate of the "Supporting Local Communities" thematic cluster (belonging to "Social Sustainability" top-level code) is $50 \%$ (see Table 3 and a few excerpts below from successful campaigns in this thematic cluster) compared to $29 \%$ of the "Local and Seasonal Food" thematic cluster (which belongs to the "Health Food" top-level code).

"It is our sincere hope that we can help secure a future for small-scale British farming operations. (...) We hope that the locally sourced food we provide will generate conversation around the importance of securing a future for the small-scale farmers that produce it" [Enroot] 
"We are a group of Anfield residents working to re-open our local bakery in community ownership, in a part of Liverpool where the community has lost many of its resources and amenities." [An oven at the heart of Anfield]

These observations bring us to the first two propositions:

P1a: In reward-based CF, the sustainability attribute of localness increases the likelihood of SO projects of being financed.

P1b:In reward-based CF, the sustainability attribute of localness emphasizing support to local communities and cultures (public benefits ownership) positively influences backers' funding decisions more than that emphasizing healthiness (private benefits ownership)

While the first proposition is in line with the literature on purchasing behavior, which highlights the growing interest by consumers towards the localness attribute of food products (e.g., Feldman and Hamm, 2015), the second proposition contrasts with previous literature, which instead suggests that privately appropriated values (such as healthiness and taste) drive food choices much more strongly than publicly-oriented attributes (such as social fairness, environmental impact, farmland preservation) (Lusk and Briggeman, 2009; Costanigro et al., 2011).

We advance that such a contrast with previous literature for the specific attribute of localness may stem from two factors. On the one side, since the 1990s there has been a growing emphasis in the public arena on the importance of purchasing local products to contributing to the development and sustainability of local areas (McDonagh and Commins, 1999; Ilbery and Kneafsey, 1999; Murdoch et al., 2000; Bellows and Hamm, $2001)^{8}$. On the other side, financing a crowdfunding initiative is a public act more than purchasing a good in a store in an everyday shopping experience. Therefore, backers may be led to give greater importance to a publicly oriented attribute because it affects their perceived reputation in the online community and the ability to enhance their social recognition (Belk, 2013), or because they wish to state/remark a principle. Indeed, the literature about consumers' behavior towards sustainable food has noted that some consumers desire to make sustainable statements or send social messages (Vecchio and Annunziata, 2013). This may be especially true when the loose ideology of the platform hosting the crowdfunding campaign is largely supportive of a sustainability orientation, like in the case of Kickstarter (Calic and Mosakowski, 2016). Furthermore, consumer studies (see e.g., Rokka and Uusitalo, 2008) claim that the importance of product attributes is influenced by the specific decision situations (in this case, contributing money on a public arena such as a crowdfunding platform versus private shopping in a store). Based on these observations, we can conclude that in the context of $\mathrm{CF}$ and more in general in situations where the given act is somewhat publicly

\footnotetext{
${ }^{8}$ It is worth noting that some authors (e.g., Hinrichs, 2003; Winter, 2003) warn against an easy dichotomy between the good local and the bad global.
} 
observed, publicly oriented attributes of localness may drive decisions more strongly than those emphasizing self-centered/privately appropriated values.

However, it is surprising that, in contrast with $\mathrm{P} 1 \mathrm{~b}$, data collected regarding all the other thematic clusters show a huge difference in terms of success between projects emphasizing self-centered and individualistic attributes - beyond sustainability attributes - compared to those that do not. Projects giving large importance to product's taste and using words such as "delicious", "tasteful" and "gourmet" have a success rate of 47\% compared to a success rate of $25 \%$ of those projects that do not emphasize product's taste and other personal benefits (see a few excerpts below from successful campaigns emphasizing self-centered attributes beyond sustainability attributes).

"We seek out only the best quality cocoa beans and try to deal directly with farmers and co-operatives. By paying for quality, we are able to pay up to five times the market rate for beans, ensuring better quality chocolate and a better standard of living for farmers. (...) It allows us to produce a chocolate that not only tastes great, but helps support farmers in some of the poorest parts of the world." [Artisan Chocolate Bars Delivered To Your Door]

"Using proven cheese making procedures from traditional cheese production, we've created an all-vegan product that tastes incredible and comes amazingly close in texture and feeling to the original. (...). We believe our produce is the way of things to come - a gourmet product with exquisite taste and culinary value." [Happy Cheeze - Vegan and Raw]

These observations bring us to the following proposition:

P2: In reward-based $\mathrm{CF}$, the emphasis on self-centered attributes beyond sustainability attributes increases the likelihood of SO projects of being financed.

Such a proposition is consistent with the literature on consumer purchase decisions of sustainable products (Hobbs et al., 2006; Combris et al., 2009). Indeed, in spite of a few exceptions (e.g., Bougherara and Combris, 2009), most of the studies in this field suggest that sustainable products are chosen not only for altruistic reasons (e.g., for animal welfare) but also for self-centered reasons, such as personal taste benefits. Consumers engaging in any economic act are indeed driven by multiple motivations, not only purely altruistic or simply utilitarian motivations, but a sort of hybrid often based on the norm of reciprocity (Andreoni, 1990; Grant, 2013). This is particularly true for backers in the reward-based CF context. Indeed, the reward-based CF platforms foster reciprocal giving among their members (project proponents and backers) beyond pure altruism and self-interest (Colombo et al., 2015; André et al., 2017). Taken together, these arguments suggest that consumers may be more prone to respond to stimuli that involve both utilitarian and altruistic motivations. Therefore, backers in reward-based CF should have greater incentive to fund SO projects that endeavor to satisfy both self-centered (e.g., personal taste) and societal (e.g., sustainability) benefits, rather than SO projects exclusively targeting the latter type of benefits. 
The difference between projects characterized by localness attribute (see P1b) and all other projects (see P2) can be explained by the fact that since the 1990s a general consensus exists about the assumption that small local food production may substantially contribute to the development and sustainability of local areas, protecting them from depletion and depopulation (McDonagh and Commins, 1999; Ilbery and Kneafsey, 1999; Murdoch et al., 2000; Bellows and Hamm, 2001).Such a dominant consensus may suggest that when consumers decide to purchase on the basis of local attribute it is mainly done for social/sustainability reasons and not for pursuing personal benefits.

Another interesting insight derived from our qualitative investigation is that SO campaigns pursuing products or services whose main sustainability attribute is "Helping People in Need" show a relatively poor performance (the success rate is $27 \%$ ). These campaigns do not refer either to local or remote communities/producers. That is, this sustainable attribute is unrelated to any geographic categorization. Rather, these campaigns generally refer to helping disadvantaged individuals (such as the homeless, people with disabilities or former alcohol abusers) irrespective of their geographic location. The relatively high failure rate of projects in this thematic cluster may be explained by the fact that, as already outlined in Section 3, while many people believe that consumers have a responsibility not to do harm, they do not believe that others have a right to be helped (Folkes and Kamins, 1999) by means of their purchasing decisions. Thus, backers are more likely to deem the topic (i.e., helping disadvantaged individuals) more appropriate for charity (and therefore donation-based fundraising) or lending activities than for entrepreneurial sustainability-oriented initiatives available in reward-based CF. Such a consideration is in line with research results. In a lending-based setting, for example, results reported by Allison et al. (2013; 2015) show that projects emphasizing pro-social causes are more successful than those that do not. Furthermore, Moritz et al. (2015) expect that, in donation-based crowdfunding, what matters is the presentation of the social value of the project while in reward-based CF the presentation of product features. The debate whether CF could be considered an online charity or a tool for entrepreneurial initiatives is still open (Profatilov et al., 2015). However, reward-based CF platforms such as Kickstarter keep away from the donation model, explicitly stating that "projects can't fundraise for charity" and "While nonprofits are welcome to launch projects on Kickstarter, projects can't promise to raise funds to donate to a charity or cause." Rather, "Projects must create something to share with others." Hence, reward-based CF platforms can be viewed like platforms for (risky) pre-ordering of not yet developed products/services, rather than channels for donations. As a consequence, backers accessing these platforms tend to be more restrained in supporting projects aimed at helping disadvantaged individuals/groups (in spite of the fact that these projects offer some reward anyway) because they perceive such projects less consistent within the full logic and scopes of reward-based CF.

Accordingly, we propose the following: 
P3: In reward-based CF, products/services attributes targeting disadvantaged individuals/groups decrease the likelihood of SO projects of being financed.

Figure 1 presents the framework that summarizes the propositions that were derived from our qualitative data analysis (Eisenhardt, 1989).

\section{Insert here figure 1}

\section{Conclusions, limitations and future developments}

A common goal of current research is to uncover whether CF could be considered or not a way to support sustainability-oriented initiatives in securing funding, In our view, the objective of proving this could be misplaced; rather, we deem more fruitful to understand how critical are some attributes of products/services pursued within CF campaigns to benefiting sustainability-oriented initiatives and increasing their odds of success in CF. In order to collect insights on these product/service attributes, we decided to address this research question focusing on food because it is the area where sustainability issues apply more than to any other human activities, being food provision the human activity with the single largest environmental impact (Aiking and De Boer, 2004; Notarnicola et al., 2017) and the human activity having a unique set of sustainability issues also on social fronts (Pullman et al., 2009). By adopting a rigorous qualitative approach, this paper provides both theoretical and empirical contributions to the literature as well as practical implications.

Concerning theoretical contributions, literature already recognizes the importance of project-related (Hörisch, 2015; Calic and Mosakowski, 2016; Hörisch, 2018), founder-related (Bonzanini et al., 2015; Calic and Mosakowski, 2016), project finance-related (Bonzanini et al., 2015) as well as platform-related (Bonzanini et al., 2015; Vasileiadou et al., 2015; Calic and Mosakowski, 2016) attributes on SO campaigns' success. To our knowledge, there are not studies that have instead addressed the role of specific product/service attributes pursued within SO campaigns in determining the success of such campaigns and thus the extent to which CF can support funding of SO projects. Grounding on previous literature claiming that product/service attributes do have an impact on consumer purchasing decisions of sustainable products (e.g., Crane, 2001; Auger et al., 2003; 2008; 2010; Bougherara and Combris, 2009; Vecchio and Annunziata, 2013), our results suggest that also in CF some product/service attributes may have an impact on the success of sustainability-oriented initiatives. Specifically, our qualitative research suggests that, like in purchasing decisions (e.g. Schuitema et al., 2015; Annunziata and Scarpato, 2014), backers do consider sustainability attributes in their CF financing decisions, but together with egoistic/self-centered product attributes. Compared with egoistic/self-centered ones, altruistic/society centered product attributes are shown to prevail in the case of localness attribute only, which may be due to the dominant discourse around it. Finally, in line with purchasing decisions literature (e.g. Folkes and Kamins, 1999), it also emerges that while many people believe that consumers have a responsibility not to do harm, they do not believe that others have a right to be 
helped by means of a purchasing or a CF financing decision. It is worth noting that such product/service attributes may interact with other attributes such as campaign-related, platform-related and founder-related attributes, therefore making it extremely difficult to disentangle which factors or combinations of them have the largest impact on the campaign success. This interplay may also explain the conflicting observations emerging in literature investigating the role of CF in supporting sustainability-oriented initiatives, and that stimulated us to undertake our research.

Concerning empirical contributions, our research provides insights on a sector (i.e. food) that, until now, has been largely neglected in CF studies in spite of its increasing importance in connection with sustainability issues. In this regard, our study expands CF research, going beyond traditionally investigated sectors such as entertainment and technology. What emerges from the research is that reward-based CF's contribution to supporting sustainability-oriented initiatives in the food landscape is still limited, both in terms of target goals, funding obtained per project and number of backers (see Table 1). Our results seem to be in line with the more general findings by Hynes and Wilson (2016) that social media are not at the moment very effective in bringing large-scale change towards sustainability.

Concerning practical implications, our observations would also provide CF campaigns' proponents with suggestions on how to design and communicate their products/services to be launched by means of a CF campaign. In terms of attributes embedded in products/services, they should try to emphasize features related to local production and development, specifically, local origin attribute of products/services, as suggested by our propositions P1a, as well as, generally speaking, communicate the sustainability benefits of their products/services in conjunction with potential personal benefits for backers (self-centered attributes) as these seem to affect the success of SO campaigns considerably, as suggested by our proposition P2. However, our study also informs SO campaigns' proponents that, if they target localness attributes, they may consider placing more emphasis on public benefits, rather than on personal benefits for backers (as suggested by our Proposition P1b). Finally, proponents of SO projects whose products/services are addressing disadvantaged individuals/groups may consider more suitable to launch CF campaigns on donation-based platforms rather than on reward-based platforms (Proposition P3).

As for every research, there are of course some limitations, which however offer remarkable opportunities for future research. First, future studies should formalize hypotheses based on the developed propositions and test them by means of quantitative research methods in broader samples and perhaps different contexts (for instance using different platforms). Other product/service attributes should be considered, beyond those emerged from our qualitative analysis. Furthermore, in our sample, SO projects make up a small portion (21\%) of all projects identified in the period under investigation. As noted by Bartenberger and Leitner (2013) as well as Hörisch (2015), generalist platforms such as Kickstarter may insufficiently support initiatives addressing societal problems. Therefore, we expect to gain further useful insight on the role of CF in supporting sustainability-oriented initiatives by also analysing CF platforms such as Barnraiser, a platform 
specialized in funding sustainable food initiatives. In addition, our dataset is completely restricted to rewardbased $\mathrm{CF}$, which is an important form of $\mathrm{CF}$ but not the biggest. Future research should address whether other results can be observed if the sample is made of other types of CF such as equity-based CF or lendingbased CF, which are other two prominent forms of CF. In these cases, however, adopting a purchasing decision lens would not be the most appropriate lens, therefore calling for other sources of inspiration. Finally, our analysis includes campaigns until December 2015, thus embracing a period in which the European CF was still in its growth period. Repeating our research in five years when CF will possibly reach its maturity phase would provide new insights to compare with extant ones.

Besides overcoming these limitations, future research could gain advantage by further investigating the relative importance of these attributes - as it is traditionally done in the consumer purchase behavior literature -, and by identifying different groups of backers. Indeed, this literature, while documenting a broad interest towards sustainability by individuals and groups, claims that there are great differences among various consumer groups, particularly according to gender, educational level, income, age and so forth (Torjusen et al., 2001; Ubilava et al., 2010; Vecchio and Annunziata, 2013: Hinnen et al., 2017). We expect that these differences towards sustainability will emerge also in the context of CF, i.e., among backers.

Finally, it is worth noting that the extent to which we can generalize our results is an issue that arises in every qualitative analysis and that this problem is further exacerbated in this case by the fact that we focused on a single sector, i.e., food. As we have largely discussed, the food industry is arguably one of the most suitable templates for studying how CF can support SO projects due to the relevance of the industry itself, the growing popularity of $\mathrm{CF}$ for food industry, and the importance of sustainability issues in the food industry. However, we recognize that this sector implies specific motivations of backers to participate, specific product or service attributes (which significantly emerged from our qualitative analysis), and specific cultural approaches. This means that generalization to other sectors requires caution and should not be undertaken without further research, also taking into consideration that consumers' evaluation of sustainability attributes tends to be context specific (Devinney et al., 2006). Despite these limits to generalization, we believe that this research can serve to channel greater attention to products/services attributes (whatever they are and whatever their effects are) when seeking to understand CF in the sustainability context. Indeed, some of our results could arguably apply to other industries where sustainability issues play a relevant role. For instance, the proposition (P2) on the effect of offering selfcentered/egoistic benefits (in addition to those which are sustainability-related) may well apply to other project categories available in CF platforms, such as renewable energy. This is because the idea is that backers of CF projects need to be stimulated by more direct, immediate and tangible benefits, given that they tend to choose sustainable products (regardless of whether it is food, or renewable energy, etc.) not only for altruistic or social reasons, but also for selfish reasons (e.g., Hobbs et al., 2006; Combris et al., 2009). Similarly, the beneficial role of targeting local communities and cultures (P1a/P1b) may well apply to food industry but also to a vast range of handicraft products available in CF platforms and supporting local and 
environmentally friendly productions. Similar extension may also be done for proposition P3 because the tendency to deem campaigns trying to help disadvantaged communities/individuals more appropriate for charity or micro-lending initiatives rather than for sustainability-oriented entrepreneurial initiatives launched via reward-based CF platforms is something that impacts not only on food-related projects but also on other project categories, such as clothing.

\section{References}

Aertsens, J., Verbeke, W., Mondelaers, K., \& Van Huylenbroeck, G. (2009). Personal determinants of organic food consumption: a review. British Food Journal, 111(10), 1140-1167.

Aiking, H., \& De Boer, J. (2004). Food sustainability: Diverging interpretations. British Food Journal, 106(5), 359-365.

Aitamurto, T. (2011). The impact of crowdfunding on journalism: Case study of Spot. Us, a platform for community-funded reporting. Journalism Practice, 5(4), 429-445.

Allison, T. H., McKenny, A. F., \& Short, J. C. (2013). The effect of entrepreneurial rhetoric on microlending investment: An examination of the warm-glow effect. Journal of Business Venturing, 28(6), 690-707.

Allison, T. H., Davis, B. C., Short, J. C., \& Webb, J. W. (2015). Crowdfunding in a prosocial microlending environment: Examining the role of intrinsic versus extrinsic cues. Entrepreneurship Theory and Practice, 39(1), 53-73.

Allison, T., H., Davis, B. C., Webb, J. W., \& Short, J. C. (2017). Persuasion in crowdfunding: An elaboration likelihood of crowdfunding performance. Entrepreneurship Theory and Practice, 32(6), 707 725.

André, K., Bureau, S., Gautier, A., \& Rubel, O. (2017). Beyond the opposition between altruism and selfinterest: Reciprocal giving in reward-based crowdfunding. Journal of Business Ethics, 146(2), 313-332.

Andreoni, J. (1990). Impure altruism and donations to public goods: A theory of warm-glow giving. The Economic Journal, 100(401), 464-477.

Annunziata, A., \& Scarpato, D. (2014). Factors affecting consumer attitudes towards food products with sustainable attributes. Agricultural Economics, 60(8), 353-363.

Arcese, G., Flammini, S., Lucchetti, M. C., \& Martucci, O. (2015). Evidence and experience of open sustainability innovation practices in the food sector. Sustainability, 7(7), 8067-8090.

Arunachalam, B., Henneberry, S. R., Lusk, J. L., \& Norwood, B. F. (2009). An Empirical Investigation into the Excessive-Choice Effect. American Journal of Agricultural Economics, 91(3), 810-825.

Auger, P., Burke, P., Devinney, T. M., \& Louviere, J. J. (2003). What will consumers pay for social product features?. Journal of Business Ethics, 42(3), 281-304. 
Auger, P., Devinney, T. M., Louviere, J. J., \& Burke, P. F. (2008). Do social product features have value to consumers?. International Journal of Research in Marketing, 25(3), 183-191.

Auger, P., Devinney, T. M., Louviere, J. J., \& Burke, P. F. (2010) The importance of social product attributes in consumer purchasing decisions: A multi-Country comparative study. International Business Review, 19(1), 23-31.

Bartenberger, M., \& Leitner, P. (2013). Crowdsourcing and crowdfunding: approaches to foster social innovation. In Proceedings of the IADIS International Conference Web Based Communities and Social Media (pp. 81-85).

Belk, R. (2013). Extended self in a digital world. Journal of Consumer Research, 40, 477-500.

Belleflamme, P., Lambert, T., \& Schwienbacher, A. (2014). Crowdfunding: Tapping the right crowd. Journal of Business Venturing, 29(5), 585-609.

Bellows, A. C., \& Hamm, M. W. (2001). Local autonomy and sustainable development: Testing import substitution in more localized food systems. Agriculture and Human Values, 18(3), 271-284.

Belz, F. M., \& Binder, J. K. (2017). Sustainable entrepreneurship: A convergent process model. Business Strategy and the Environment, 26(1), 1-17.

Bocken, N. M. (2015). Sustainable venture capital-catalyst for sustainable start-up success? Journal of Cleaner Production, 108, 647-658.

Bonzanini, D., Giudici, G., \& Patrucco, A. (2015). The crowdfunding of renewable energy projects. In Handbook of Environmental and Sustainable Finance (pp. 429-444). Academic Press.

Boyatzis, R. E. (1998). Transforming qualitative information: Thematic analysis and code development. Sage.

Bougherara, D., \& Combris, P. (2009). Eco-labelled food products: What are consumers paying for? European Review of Agricultural Economics, 36(3), 321-341.

Briggeman, B. C., \& Lusk, J. L. (2011). Playing fair in the organic food supply chain. European Review of Agricultural Economics, 26, 167-172.

Bruton, G., Khavul, S., Siegel, D., \& Wright, M. (2015). New financial alternatives in seeding entrepreneurship: Microfinance, crowdfunding, and peer-to-peer innovations. Entrepreneurship Theory and Practice, 39(1), 9-26.

Burla, L., Knierim, B., Barth, J., Liewald, K., Duetz, M., \& Abel, T. (2008). From text to codings: intercoder reliability assessment in qualitative content analysis. Nursing Research, 57(2), 113-117.

Calic, G., \& Mosakowski, E. (2016). Kicking off social entrepreneurship: How a sustainability orientation influences crowdfunding success. Journal of Management Studies, 53(5), 738-767. 
Chan, C. R., \& Parhankangas, A. (2017). Crowdfunding innovative ideas: How incremental and radical innovativeness influence funding outcomes. Entrepreneurship Theory and Practice, 41(2), 237-263.

Chiang, A. (2015). How entrepreneurs can crowdfund renewable energy projects. Journal of Business, Entrepreneurship \& Law, 8(2) 659-696.

Cholakova, M., \& Clarysse, B. (2015). Does the possibility to make equity investments in crowdfunding projects crowd out reward-based investments?. Entrepreneurship Theory and Practice, 39(1), 145-172.

Chryssohoidis, G. M., \& Krystallis, A. (2005). Organic consumers' personal values research: Testing and validating the list of values (LOV) scale and implementing a value-based segmentation task. Food Quality and Preference, 16(7), 585-599.

Colombo, M. G., Franzoni, C., \& Rossi-Lamastra, C. (2015). Internal social capital and the attraction of early contributions in crowdfunding. Entrepreneurship Theory and Practice, 39(1), 75-100.

Combris, P., Pinto, A. S., Fragata, A., \& Giraud-Héraud, E. (2009). Does taste beat food safety? Evidence from the "Pêra Rocha" case in Portugal. Journal of Food Products Marketing, 16(1), 60-78.

Costanigro, M., McFadden, D. T., Kroll, S., \& Nurse, G. (2011). An in-store valuation of local and organic apples: the role of social desirability. Agribusiness, 27(4), 465-477.

Crabtree, B. F., \& Miller, W. L. (Eds.). (1999). Doing qualitative research. Sage Publications.

Crane, A. (2001). Unpacking the ethical product. Journal of Business Ethics, 30(4), 361-373.

Deemer, D. R., \& Lobao, L. M. (2011). Public concern with farm-animal welfare: Religion, politics, and human disadvantage in the food sector. Rural Sociology, 76(2), 167-196.

DEFRA (2006). Sustainable Farming and Food Strategy: Forward Look. Department for Environment, Food and Rural Affairs. London.

Dekhili, S., \& Achabou, M. A. (2013). Price fairness in the case of green products: enterprises' policies and consumers' perceptions. Business Strategy and the Environment, 22(8), 547-560.

Demirel, P., \& Danisman, G. O. (2019) Eco-innovation and firm growth in the circular economy: Evidence from European small-and medium-sized enterprises. Business Strategy and the Environment.

Devinney, T. M., Auger, P., Eckhardt, G., \& Birtchnell, T. (2006). The other CSR: making consumers socially responsible. Stanford Social Innovation Review, 30-37.

Dóci, G., \& Vasileiadou, E. (2015). "Let's do it ourselves" Individual motivations for investing in renewables at community level. Renewable and Sustainable Energy Reviews, 49, 41-50. 
Duriau, V. J., Reger, R. K., \& Pfarrer, M. D. (2007). A content analysis of the content analysis literature in organization studies: Research themes, data sources, and methodological refinements. Organizational Research Methods, 10(1), 5-34.

Eisenhardt, K. M. (1989). Building theories from case study research. Academy of Management Review, $14(4), 532-550$.

Elliott, J. (2013). An introduction to sustainable development. Routledge.

Farla, J., Markard, J., Raven, R., \& Coenen, L. (2012). Sustainability transitions in the making: A closer look at actors, strategies and resources. Technological Forecasting and Social Change, 79(6), 991-998.

Feldmann, C., \& Hamm, U. (2015). Consumers' perceptions and preferences for local food: A review. Food Quality and Preference, 40, 152-164.

Fereday, J., \& Muir-Cochrane, E. (2006). Demonstrating rigor using thematic analysis: A hybrid approach of inductive and deductive coding and theme development. International Journal of Qualitative Methods, 5(1), 80-92.

Fischer, D., Jenssen, S., \& Tappeser, V. (2015). Getting an empirical hold of the sustainable university: a comparative analysis of evaluation frameworks across 12 contemporary sustainability assessment tools. Assessment \& Evaluation in Higher Education, 40(6), 785-800.

Flick, U., von Kardoff, E., \& Steinke, I. (Eds.). (2004). A companion to qualitative research. Sage.

Folkes, V. S., \& Kamins, M. A. (1999). Effects of information about firms' ethical and unethical actions on consumers' attitudes. Journal of Consumer Psychology, 8(3), 243-259.

Gerber, E. M., \& Hui, J. (2013). Crowdfunding: Motivations and deterrents for participation. ACM Transactions on Computer-Human Interaction, 20(6), 34.

Goodman, A., \& Polycarpou, L. (2013). The Sustainability-Social Networking Nexus. Sustainability, 6(1), 26-32.

Graneheim, U. H., \& Lundman, B. (2004). Qualitative content analysis in nursing research: concepts, procedures and measures to achieve trustworthiness. Nurse Education Today, 24(2), 105-112.

Grant, A. M. (2013). Give and take: A revolutionary approach to success. Penguin.

Harper, G. C., \& Makatouni, A. (2002). Consumer perception of organic food production and farm animal welfare. British Food Journal, 104(3/4/5), 287-299.

Harte, M. E. (2013). Climate change this week: Solar crowdfunding, wild arctic times, and more!, Huffington Post, January 13. https://www.huffpost.com/entry/climate-change-this-week_b_2469641.

Hemer, J. (2011). A snapshot on crowdfunding, Working Papers Firms and Region, No. R2/2011. Karlsruhe. Fraunhofer Institute for Systems and Innovation Research ISI. 
Van den Heuvel, T., van Trijp, H., van Woerkum, C., Renes R. J., \& Gremmen, B. (2007). Linking product offering to consumer needs: Inclusion of credence attributes and the influences of product features. Food Quality and Preference 18(2): 296-304.

Hinnen, G., Hille, S. L., \& Wittmer, A. (2017). Willingness to pay for green products in air travel: Ready for take-off?. Business Strategy and the Environment, 26(2), 197-208.

Hinrichs, C. C. (2003). The practice and politics of food system localization. Journal of Rural Studies, 19(1), $33-45$.

Hobbs, J. E., Sanderson, K., \& Haghiri, M. (2006). Evaluating willingness-to-pay for bison attributes: an experimental auction approach. Canadian Journal of Agricultural Economics/Revue Canadienne d'Agroeconomie, 54(2), 269-287.

Hörisch, J. (2015). Crowdfunding for environmental ventures: an empirical analysis of the influence of environmental orientation on the success of crowdfunding initiatives. Journal of Cleaner Production, 107, 636-645.

Hörisch, J. (2018). 'Think big' or 'small is beautiful'? An empirical analysis of characteristics and determinants of success of sustainable crowdfunding projects. International Journal of Entrepreneurial Venturing, 10(1), 111-129.

Howard, P. H., \& Allen, P. (2010) Beyond Organic and Fair Trade? An analysis of ecolabel preferences in the United States. Rural Sociology, 75, 244-69.

Hynes, N., \& Wilson, J. (2016). I do it, but don't tell anyone! Personal values, personal and social norms: Can social media play a role in changing pro-environmental behaviours?. Technological Forecasting and Social Change, 111, 349-359.

Ilbery, B., \& Maye, D. (2005). Food supply chains and sustainability: evidence from specialist food producers in the Scottish/English borders. Land Use Policy, 22(4), 331-344.

Ilbery, B., Kneafsey, M., 1999. Niche markets and regional specialty food products in Europe: Towards a research agenda. Environment and Planning A, 31, 2207-2222.

Johnston, R. J., Wessells, C. R., Donath, H., \& Asche, F. (2001). Measuring consumer preferences for ecolabeled seafood: an international comparison. Journal of Agricultural and Resource Economics, 26(1), 20-39.

Krippendorff, K. Content analysis: An introduction to its methodology. Sage Publications, Thousand Oaks, CA, USA (2004).

Kuppuswamy, V., \& Bayus, B. L. (2018). Crowdfunding creative ideas: The dynamics of project backers. In The Economics of Crowdfunding (pp. 151-182). Palgrave Macmillan, Cham. 
Lagazio, C., \& Querci, F. (2018). Exploring the multi-sided nature of crowdfunding campaign success. Journal of Business Research, 90, 318-324

Lam, P. T., \& Law, A. O. (2016). Crowdfunding for renewable and sustainable energy projects: An exploratory case study approach. Renewable and Sustainable Energy Reviews, 60, 11-20.

Lancaster, K., 1966. A new Approach to consumer theory. Journal of Political Economy, 74, 132-157.

Lefkoff-Hagius, R., \& Mason, C. H. (1990). The role of tangible and intangible attributes in similarity and preference judgments. In $N A$ - Advances in Consumer Research Volume 17 (pp. 135-143), eds. Marvin E. Goldberg, Gerald Gorn, and Richard W. Pollay, Provo, UT: Association for Consumer Research.

Lehner, O. M. (2013). Crowdfunding social ventures: a model and research agenda. Venture Capital, 15(4), 289-311.

Lehner, O. M., \& Nicholls, A. (2014). Social finance and crowdfunding for social enterprises: A publicprivate case study providing legitimacy and leverage. Venture Capital, 16(3), 271-286.

Lindenberg, S., \& Steg, L. (2007). Normative, gain and hedonic goal frames guiding environmental behavior. Journal of Social Issues, 63(1), 117-137.

Lombard, M., Snyder-Duch, J., \& Bracken, C. C. (2002). Content analysis in mass communication: assessment and reporting of intercoder reliability. Human Communication Research, 28, 587-604.

Lusk J. L., \& Briggeman B. C. (2009). Food value. American Journal of Agriculture Economics, 91(1), 184196.

Maehle, N., Iversen, N., Hem, L., \& Otnes, C. (2015). Exploring consumer preferences for hedonic and utilitarian food attributes. British Food Journal, 117(12), 3039-3063.

Magnusson, M. K., Arvola, A., Hursti, U. K. K., Åberg, L., \& Sjödén, P. O. (2003). Choice of organic foods is related to perceived consequences for human health and to environmentally friendly behaviour. Appetite, 40(2), 109-117.

McDonagh, P., \& Commins, P. (1999). Food chains, small-scale food enterprises and rural development: Illustrations from Ireland. International Planning Studies, 4(3), 349-371.

McNaught, C., \& Lam, P. (2010). Using Wordle as a supplementary research tool. The Qualitative Report, 15(3), 630-643.

Misso, R., Varlese, M., Cesaretti G. P. (2019). Food systems and sustainability: The role of crowdfunding. In Theodoridis et al. (eds.), Innovative Approaches and Applications for Sustainable Rural Development, Springer Earth System Sciences.

Mollick, E. (2014). The dynamics of crowdfunding: An exploratory study. Journal of Business Venturing, 29(1), 1-16. 
Moritz, A., Block, J., \& Lutz, E. (2015). Investor communication in equity-based crowdfunding: A qualitative-empirical study. Qualitative Research in Financial Markets, 7(3), 309-342.

Moser, R., Raffaelli, R., \& Thilmany, D. D. (2011). Consumer preferences for fruit and vegetables with credence-based attributes: a review. International Food and Agribusiness Management Review, 14 (10302016-82774), 121-142.

Moss, T. W., Neubaum, D. O., \& Meyskens, M. (2015). The effect of virtuous and entrepreneurial orientations on microfinance lending and repayment: A signaling theory perspective. Entrepreneurship Theory and Practice, 39(1), 27-52.

Murdoch, J., Marsden, T., \& Banks, J. (2000). Quality, nature, and embeddedness: Some theoretical considerations in the context of the food sector. Economic Geography, 76(2), 107-125.

Notarnicola, B., Tassielli, G., et al., 2017. Environmental impacts of food consumption in Europe. Journal of Cleaner Production, 140, pp.753-765.

Ordanini, A., Miceli, L., Pizzetti, M., \& Parasuraman, A. (2011). Crowdfunding: transforming customers into investors through innovative service platforms. Journal of Service Management, 22(4), 443-470.

Ortas, E., Burritt, R. L., \& Moneva, J. M. (2013). Socially Responsible Investment and cleaner production in the Asia Pacific: does it pay to be good?. Journal of Cleaner Production, 52, 272-280.

Park, A. (2012). Crowdfunding a cure: The sick are getting strangers to pay their medical bills. Time, $180(23), 22$.

De Pelsmacker, P., Driesen, L., \& Rayp, G. (2005). Do consumers care about ethics? Willingness to pay for fair-trade coffee. Journal of Consumer Affairs, 39(2), 363-385.

Perrini, F., Castaldo, S., Misani, N., \& Tencati, A. (2010). The impact of corporate social responsibility associations on trust in organic products marketed by mainstream retailers: A study of Italian consumers. Business Strategy and the Environment, 19(8), 512-526.

Pitschner, S., \& Pitschner-Finn, S. (2014). Non-profit differentials in crowd-based financing: Evidence from 50,000 campaigns. Economics Letters, 123(3), 391-394.

Prakash, A. (2002). Green marketing, public policy and managerial strategies. Business strategy and the environment, 11(5), 285-297.

Profatilov, D. A., Bykova, O. N., \& Olkhovskaya, M. O. (2015). Crowdfunding: Online Charity or a Modern Tool for Innovative Projects Implementation? Asian Social Science, 11(3), 146.

Pullman, M. E., Maloni, M. J., \& Carter, C. R. (2009). Food for thought: Social versus environmental sustainability practices and performance outcomes. Journal of Supply Chain Management, 45(4), 38-54. 
Raynolds, L. T., Murray, D., \& Leigh Taylor, P. (2004). Fair trade coffee: building producer capacity via global networks. Journal of International Development: The Journal of the Development Studies Association, 16(8), 1109-1121.

Reisch, L., Eberle, U., \& Lorek, S. (2013). Sustainable food consumption: An overview of contemporary issues and policies. Sustainability: Science, Practice and Policy, 9(2), 7-25.

Rokka, J., \& Uusitalo, L. (2008). Preference for green packaging in consumer product choices-do consumers care?. International Journal of Consumer Studies, 32(5), 516-525.

Roma, P., Messeni Petruzzelli, A., \& Perrone, G. (2017). From the crowd to the market: The role of rewardbased crowdfunding performance in attracting professional investors. Research Policy, 46(9), 1606-1628.

Roma, P., Gal-Or, E., \& Chen, R. R. (2018). Reward-based crowdfunding campaigns: Informational value and access to venture capital. Information Systems Research, 29(3), 679-697.

Rosen, S. (1974). Hedonic prices and implicit markets: product differentiation in pure competition. Journal of Political Economy, 82(1), 34-55.

Royal, C., \& Windsor, G. S. S. (2014). Microfinance, crowdfunding, and sustainability: A case study of telecenters in a south Asian developing country. Strategic Change, 23(7-8), 425-438.

Sachs J. D. (2015). The Age of Sustainable Development. Columbia University Press

Sandelowski, M. (1995). Qualitative analysis: What it is and how to begin. Research in Nursing \& Health, 18(4), 371-375.

Savino, T., Testa, S., \& Petruzzelli, A. M. (2018). Researcher understanding of food innovations in Nordic and Southern European countries: A systematic literature review. Trends in Food Science \& Technology, 77, 54-63.

Schäufele, I., \& Hamm, U. (2017). Consumers' perceptions, preferences and willingness-to-pay for wine with sustainability characteristics: A review. Journal of Cleaner Production, 147, 379-394.

Schuitema, G., \& De Groot, J. I. (2015). Green consumerism: The influence of product attributes and values on purchasing intentions. Journal of Consumer Behaviour, 14(1), 57-69.

SDC Sustainable Development Commission. Sustainability Implications of the Little Red Tractor Scheme. London: SDC (2005).

SDC Sustainable Development Commission. Setting the Table: Advice to Government on Priority Elements of Sustainable Diets. London: SDC (2009).

Shepherd, D. A., \& Sutcliffe, K. M. (2011). Inductive top-down theorizing: A source of new theories of organization. Academy of Management Review, 36(2), 361-380. 
Statista. (2019). Food \& beverages worldwide. https://www.statista.com/outlook/253/100/foodbeverages/worldwide.

Stempel, G. H., III. (1981). Content analysis. In G. H. Stempel III \& B. H. Westley (Eds.), Research methods in mass communication (pp. 119-131). Englewood Cliffs, NJ: Prentice Hall.

Testa, S., Nielsen, K. R., Bogers, M., \& Cincotti, S. (2019). The role of crowdfunding in moving towards a sustainable society. Technological Forecasting and Social Change, 141, 66-73.

Tallontire, A., Rentsendorj, E., \& Blowfield, M. (2001). Ethical consumers and ethical trade: A review of current literature (NRI Policy Series 12).

Thorpe, D. (2014). Crowdfunding success stories include $\$ 35,000$ for sock monkeys and $\$ 2,000$ for a dry composting toilet. Forbes, January 30. https://www.forbes.com/sites/devinthorpe/2013/01/30/crowdfundingsuccess-stories-include-35000-for-sock-monkeys-and-2000-for-a-dry-composting-toilet/\#271a5a7b7b69.

Torjusen, H., Lieblein, G., Wandel, M., \& Francis, C. A. (2001). Food system orientation and quality perception among consumers and producers of organic food in Hedmark County, Norway. Food quality and Preference, 12(3), 207-216.

Ubilava, D., Foster, K. A., Lusk, J. L., \& Nilsson, T. (2010). Effects of income and social awareness on consumer WTP for social product attributes. Technological Forecasting and Social Change, 77(4), 587-593.

Vecchio, R., \& Annunziata, A. (2013). Consumers' attitudes towards sustainable food: A cluster analysis of Italian university students. New Medit, 12(2), 47-56.

Vasileiadou, E., Huijben, J. C. C. M., \& Raven, R. P. J. M. (2015). Three is a crowd? Exploring the potential of crowdfunding for renewable energy in the Netherlands. Journal of Cleaner Production, 30, 1-14.

Vismara, S. (2019). Sustainability in equity crowdfunding. Technological Forecasting and Social Change, 141, 98-106.

Whetten, D. A. (1989). What constitutes a theoretical contribution? Academy of Management Review, 14(4), 490-495.

De Wet, J., \& Erasmus, Z. (2005). Towards rigour in qualitative analysis. Qualitative Research Journal, $5(1), 27$.

Willer, H., \& Kilcher, L. (2012). The World of Organic Agriculture: Statistics and Emerging Trends 2012. ed. Research Institute of Organic Agriculture (FiBL), and International Federation of Organic Agricultural Movements (IFOAM), Bonn.

WCED (World Commission on Environment and Development), (1987). Our Common Future. Report of the World Commission on Environment and Development. 
Winter, M. (2003). Embeddedness, the new food economy and defensive localism. Journal of Rural Studies, 19(1), 23-32.

Yin, R. K. (2017). Case study research and applications: Design and methods. Sage publications. 


\begin{tabular}{lcccc}
\hline \multicolumn{1}{c}{ Features } & Mean & Min & Max & Median \\
\hline Target Goal $(\boldsymbol{\epsilon})$ & 33,271 & 54 & $1,000,000$ & 10,000 \\
\hline Funding obtained $(\boldsymbol{\epsilon})$ & 4,699 & 0 & 154,521 & 435 \\
\hline Backers' Number & 68 & 0 & 1,139 & 9 \\
\hline
\end{tabular}

Table 1 - Summary statistics 


\begin{tabular}{lccc}
\hline & $\begin{array}{c}\text { Total } \\
\text { Projects }\end{array}$ & $\begin{array}{c}\text { Successful } \\
\text { Projects }\end{array}$ & $\begin{array}{c}\text { Success } \\
\text { Rate }\end{array}$ \\
\hline & 235 & 84 & $36 \%$ \\
\hline So Projects & 61 & 22 & $36 \%$ \\
\hline Healthy Food & 83 & 34 & $41 \%$ \\
\hline $\begin{array}{l}\text { Environment } \\
\text { Sustainability }\end{array}$ & 35 & 12 & $34 \%$ \\
\hline $\begin{array}{l}\text { Social } \\
\text { Sustainability }\end{array}$ & 56 & 16 & $29 \%$ \\
\hline $\begin{array}{l}\text { Animal } \\
\text { Welfare }\end{array}$ & & & \\
\hline
\end{tabular}

Table 2: SO projects split by top-level codes. 


\begin{tabular}{|c|c|c|c|c|}
\hline $\begin{array}{l}\text { Top-level } \\
\text { code }\end{array}$ & $\begin{array}{l}\text { Second-level } \\
\text { code }\end{array}$ & Value Proposition & Illustrative example ${ }^{1}$ & Campaign \\
\hline Healthy Food & $\begin{array}{l}\text { 1.Maximize } \\
\text { health } \\
\text { efficiency }(18 \\
\text { projects, } 7 \\
\text { successful) }\end{array}$ & $\begin{array}{l}\text { Products similar in taste to the } \\
\text { originals but, for example, lower in } \\
\text { fat, sugar or salt or with enhanced } \\
\text { nutrition }\end{array}$ & $\begin{array}{l}\text { Gula has set itself one single challenge: turning all snack breaks into } \\
\text { healthy but indulgent moments. (...) Gula is creating a box purely } \\
\text { dedicated to healthy snacks (...) that thanks to better information, we } \\
\text { know how to look after ourselves, and are eager to find the right snacks } \\
\text { to accompany our efforts. In order to help people to eat healthy, we are } \\
\text { launching a weekly personalized snack box. Do you have a sweet-tooth } \\
\text { and are you keeping an eye on your figure? Let us take care of your } \\
\text { box: it will include a lot of dried fruit, low in calories but sweet to the } \\
\text { taste. }\end{array}$ & $\begin{array}{l}\text { Gula - La Révolution } \\
\text { de la Pause } \\
\text { Gourmande! }\end{array}$ \\
\hline Healthy Food & $\begin{array}{l}\text { 2. Increase } \\
\text { consumption } \\
\text { of local and } \\
\text { seasonal food } \\
\text { (17 project, } 5 \\
\text { successful) }\end{array}$ & $\begin{array}{l}\text { Products sold not far from origin in } \\
\text { their harvesting season }\end{array}$ & $\begin{array}{l}\text { "We started Ursa Minor with the desire to supply fresh, delicious } \\
\text { produce using local and in season ingredients.(...). To us, nothing can } \\
\text { beat the North Coast and although we can be partial to wheaten or } \\
\text { soda bread we want to bake something different in the hope of } \\
\text { complementing the traditional with Ursa Minor's ethos of local, real and } \\
\text { fresh healthy ingredients in an effort to be part of the already growing } \\
\text { reputation of Northern Ireland as a top food destination." }\end{array}$ & $\begin{array}{l}\text { Ursa Minor } \\
\text { Bakehouse }\end{array}$ \\
\hline Healthy Food & $\begin{array}{l}\text { 3-Avoid } \\
\text { synthetic } \\
\text { pesticides and } \\
\text { chemical } \\
\text { fertilizers in } \\
\text { production } \\
\text { process - } \\
\text { Organic food } \\
\text { (26 projects, } \\
11 \text { successful) }\end{array}$ & $\begin{array}{l}\text { Products/services based on } \\
\text { organic farming. Health primarily } \\
\text { emphasized. }\end{array}$ & $\begin{array}{l}\text { "Balm Pots Organics turns organic ingredients into edible delights! No } \\
\text { chemicals, no parabens, no nasties, (...) The reduced chemical content } \\
\text { in organic products means decreased risks to health; cancers, } \\
\text { gastrointestinal problems, respiratory problems form aerosols-the } \\
\text { benefits far outweigh the cost." }\end{array}$ & Balm Pots Organic \\
\hline
\end{tabular}

\footnotetext{
${ }^{1}$ The quotations in the table were translated from original language into English, if needed
} 


\begin{tabular}{|c|c|c|c|c|}
\hline $\begin{array}{l}\text { Top-level } \\
\text { code }\end{array}$ & $\begin{array}{l}\text { Second-level } \\
\text { code }\end{array}$ & Value Proposition & Illustrative example ${ }^{1}$ & Campaign \\
\hline $\begin{array}{l}\text { Environmental } \\
\text { Sustainability }\end{array}$ & $\begin{array}{l}\text { 4. Maximize } \\
\text { material and } \\
\text { energy } \\
\text { efficiency (53 } \\
\text { projects, } 18 \\
\text { successful) }\end{array}$ & $\begin{array}{l}\text { Products or services that do more } \\
\text { with fewer resources, generating } \\
\text { less waste, emissions and } \\
\text { pollution compared to } \\
\text { product/services that deliver } \\
\text { similar functionality (Bocken et al, } \\
2014 \text { ) }\end{array}$ & $\begin{array}{l}\text { "Less waste, less packaging, no aluminum in a land-fill. (...) You will } \\
\text { become part of a community building a better coffee pod solution: we } \\
\text { are actively investing money from every pod to launch the bio- } \\
\text { degradable pod that the world needs so badly." }\end{array}$ & $\begin{array}{l}\text { Speciality Organic } \\
\text { Nespresso } \\
\text { Compatible } \\
\text { Capsules }\end{array}$ \\
\hline $\begin{array}{l}\text { Environmental } \\
\text { Sustainability }\end{array}$ & $\begin{array}{l}\text { 5. Create } \\
\text { value from } \\
\text { waste (14 } \\
\text { projects, } 5 \\
\text { successful) }\end{array}$ & $\begin{array}{l}\text { Products or services whose input } \\
\text { are existing waste streams } \\
\text { (Bocken et al., 2014) }\end{array}$ & $\begin{array}{l}\text { "Used coffee grounds are an enormous waste stream and they're also } \\
\text { perfect for growing gourmet Oyster mushrooms! (...) Right from the } \\
\text { start, we were inspired by the beauty of taking waste and turning it into } \\
\text { delicious food. But what really drives us is the potential this holds to be } \\
\text { done in cities all over the world wherever there is an abundance of } \\
\text { coffee waste. Picture a future where cities all around the world have } \\
\text { people turning this massive waste stream into delicious food. It sounds } \\
\text { good doesn't it?" }\end{array}$ & $\begin{array}{l}\text { GroCycle Urban } \\
\text { Mushroom Farm }\end{array}$ \\
\hline $\begin{array}{l}\text { Environmental } \\
\text { Sustainability }\end{array}$ & $\begin{array}{l}\text { 6. Protect } \\
\text { biodiversity } \\
\text { (12 projects, } 7 \\
\text { successful) }\end{array}$ & $\begin{array}{l}\text { Products or services aimed at } \\
\text { protecting the variety and } \\
\text { variability of life on Earth }\end{array}$ & $\begin{array}{l}\text { "Greece is a country with an impressive biodiversity: nearly } 20 \% \text { of the } \\
\text { plants that grow there are endemic, which means you cannot find them } \\
\text { anywhere else in the world! (...) The small gatherers and farmers who } \\
\text { usually make the finest varieties available don't have the means to } \\
\text { make their products be seen on a larger scale, and thus only operate } \\
\text { on local levels. If Greece is where there is the greater biodiversity of } \\
\text { some of the finest herbs of the Mediterranean, then why not make a } \\
\text { company that helps those farmers to go forward in the growing, } \\
\text { providing this pure goodness to city cooks?" }\end{array}$ & $\begin{array}{l}\text { Daphnis and Chloe: } \\
\text { Tiny farms, } \\
\text { Delicious herbs }\end{array}$ \\
\hline
\end{tabular}




\begin{tabular}{|c|c|c|c|c|}
\hline $\begin{array}{l}\text { Top-level } \\
\text { code }\end{array}$ & $\begin{array}{l}\text { Second-level } \\
\text { code }\end{array}$ & Value Proposition & Illustrative example ${ }^{1}$ & Campaign \\
\hline $\begin{array}{l}\text { Environmental } \\
\text { Sustainability }\end{array}$ & $\begin{array}{l}\text { 7. Educate to } \\
\text { sustainability } \\
\text { (4 projects, } 3 \\
\text { successful) }\end{array}$ & $\begin{array}{l}\text { Product and service solutions } \\
\text { promoting sustainable behaviors }\end{array}$ & $\begin{array}{l}\text { Help us run inspirational, interactive and educational events for anyone } \\
\text { who wants to know more about eating bugs! We have already run a few } \\
\text { insect-eating events (...) Our events have been enormously successful. } \\
\text { Adults and children alike love to find out more about insect foods, and } \\
\text { to hear some of the stories behind them. We create an open-minded, } \\
\text { thought-provoking but playful atmosphere, in which people of all ages } \\
\text { can find out more about eating bugs... For our next step, we'd like to } \\
\text { collaborate as a larger team, and to scale up - with your help! }\end{array}$ & Bug Banquet \\
\hline $\begin{array}{l}\text { Social } \\
\text { Sustainability }\end{array}$ & $\begin{array}{l}\text { 8. Support } \\
\text { local } \\
\text { communities } \\
\text { (10 projects, } 5 \\
\text { successful) }\end{array}$ & $\begin{array}{l}\text { Locally produced goods and } \\
\text { services for strengthening local } \\
\text { economy, increasing jobs, } \\
\text { encouraging local prosperity and } \\
\text { so forth. Social benefits primarily } \\
\text { emphasized. }\end{array}$ & $\begin{array}{l}\text { "We strongly believe that there is an ever-increasing disconnect } \\
\text { between the food people eat and the farmers who produce it. Enroot's } \\
\text { ambition is to bridge the widening gap between producers and } \\
\text { consumers by removing the barriers separating them. (...) It is our } \\
\text { sincere hope that we can help secure a future for small-scale British } \\
\text { farming operations. (...) We hope that the locally sourced food we } \\
\text { provide will generate conversation around the importance of securing a } \\
\text { future for the small scale farmers that produce it" }\end{array}$ & Enroot \\
\hline $\begin{array}{l}\text { Social } \\
\text { Sustainability }\end{array}$ & $\begin{array}{l}\text { 9. Support } \\
\text { communities } \\
\text { in developing } \\
\text { countries - } \\
\text { Fair trade (14 } \\
\text { projects, } 4 \\
\text { successful) }\end{array}$ & $\begin{array}{l}\text { Products obtained by means of } \\
\text { trading partnerships based on } \\
\text { dialogue, transparency and } \\
\text { respect, which seek greater equity } \\
\text { in international trade }\end{array}$ & $\begin{array}{l}\text { "We seek out only the best quality cocoa beans and try to deal directly } \\
\text { with farmers and co-operatives. By paying for quality, we are able to } \\
\text { pay up to five times the market rate for beans, ensuring better quality } \\
\text { chocolate and a better standard of living for farmers. (...) It allows us to } \\
\text { produce a chocolate that not only tastes great, but helps support } \\
\text { farmers in some of the poorest parts of the world." }\end{array}$ & $\begin{array}{l}\text { Artisan Chocolate } \\
\text { Bars Delivered To } \\
\text { Your Door }\end{array}$ \\
\hline
\end{tabular}




\begin{tabular}{|c|c|c|c|c|}
\hline $\begin{array}{l}\text { Top-level } \\
\text { code }\end{array}$ & $\begin{array}{l}\text { Second-level } \\
\text { code }\end{array}$ & Value Proposition & Illustrative example ${ }^{1}$ & Campaign \\
\hline $\begin{array}{l}\text { Social } \\
\text { Sustainability }\end{array}$ & $\begin{array}{l}\text { 10. Help } \\
\text { people in need } \\
\text { (11 projects, } 3 \\
\text { successful) }\end{array}$ & $\begin{array}{l}\text { Food-related initiatives aimed at } \\
\text { engaging in society people with } \\
\text { several problems, from homeless } \\
\text { individuals to autistics to alcohol } \\
\text { abusers. }\end{array}$ & $\begin{array}{l}\text { "I want to create an alcohol free venue that offers all the same perks as } \\
\text { a usual bar/restaurant. I am and I know many other people in recovery } \\
\text { for misuse and addiction to alcohol and substances" }\end{array}$ & $\begin{array}{l}\text { To create a } \\
\text { recovery bar/club for } \\
\text { addicts }\end{array}$ \\
\hline Animal Welfare & $\begin{array}{l}\text { 11. Improve } \\
\text { farm animal } \\
\text { welfare }(28 \\
\text { projects, } 5 \\
\text { successful) }\end{array}$ & $\begin{array}{l}\text { Food-related initiatives aimed at } \\
\text { minimizing harms to farm animals } \\
\text { wherever and to the extent } \\
\text { possible, regardless of the human } \\
\text { intention and purpose behind } \\
\text { them. }\end{array}$ & $\begin{array}{l}\text { "Our grazing pigs are allowed to experience each season once. We } \\
\text { want to offer the animals this period that is also needed for a good } \\
\text { maturation of the meat. However, a year means a lot of straw, large } \\
\text { areas of clover and some scoop shot." }\end{array}$ & $\begin{array}{l}\text { Potsdamer } \\
\text { SauenHain }\end{array}$ \\
\hline Animal Welfare & $\begin{array}{l}\text { 12. Avoid } \\
\text { consumption } \\
\text { of animal } \\
\text { ingredients - } \\
\text { Vegan food } \\
\text { (28 projects, } \\
11 \text { successful) }\end{array}$ & $\begin{array}{l}\text { Producing/delivering/informing } \\
\text { about products obtained avoiding } \\
\text { the use of animal ingredients for } \\
\text { any purpose }\end{array}$ & $\begin{array}{l}\text { "Making chocolate how it is meant to be, all vegan, no refined sugars, } \\
\text { no additives, no guilt, just pure enjoyment of raw chocolate." }\end{array}$ & $\begin{array}{l}\text { The best Raw and } \\
\text { Vegan Chocolate - } \\
\text { Loving every bite }\end{array}$ \\
\hline
\end{tabular}

Table 3: Sustainability attributes of products/services pursued within SO campaigns, split by thematic clusters (second-level codes). 


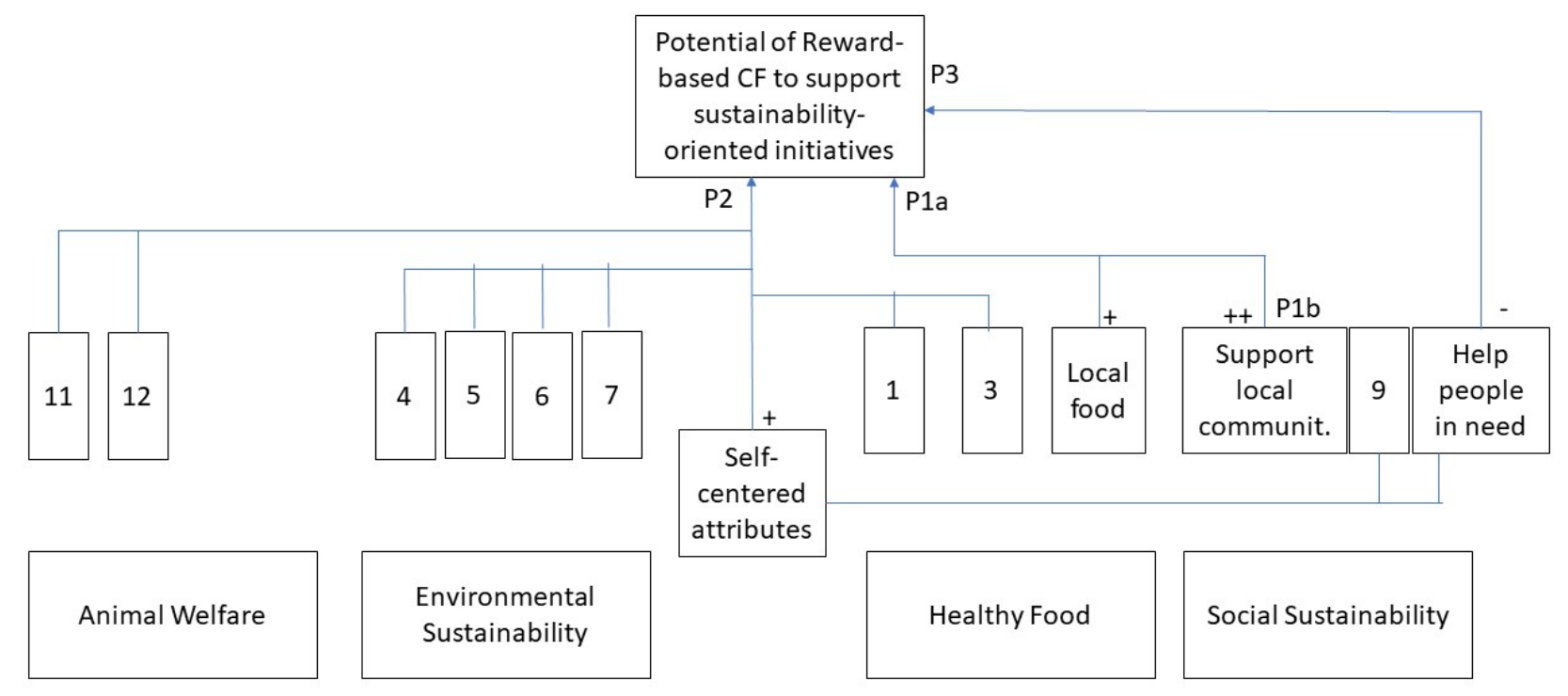

Figure 1 - Conceptual framework summarizing the propositions developed. Numbers reported in boxes refer to the second-level code of table 3. 